\title{
WYATT, ALAMANNI, AND LITERARY IMITATION
}

\author{
BY DONALD L. GUSS
}

DR. Guss, currently in the Rutgers University Department of English, received his doctorate from the University of $W$ isconsin. His special interest is in studying the development of Petrarchism in France, Italy, and England.

\section{I}

$\mathrm{N}$ the Special Collections of the Rutgers University Library there is a copy of the Opere toscane di Luigi Alamanni, ad $R e^{\prime}$ Francesco Primo (published in I 532, probably by Filippo di Giunta in Florence). Luigi Alamanni ( I 495-I 556) is one of the most important of what might be called the imitative vernacular humanists. At the end of the fifteenth century, Italian humanists like Politian and Sannazaro still generally employed Romance forms when they wrote in Italian, though their sensibilities were modified by their classical learning; by the second half of the sixteenth century Italian writers had largely abandoned imitation and were seeking in the classics general critical rules. Alamanni is a chief figure of the intermediary stage, where poets in Italian followed Latin and Greek models; he was among the first to write classical epics, tragedies, comedies, elegies, epigrams, Pindaric odes, and satires in the vernacular. His great influence was due to his practice of literary imitation. ${ }^{1}$

Like Alamanni, Sir Thomas Wyatt is a humanist, as the difference between his satires and Skelton's, and between his Petrarchan verses and the court lyrics of his predecessors, makes clear. And like Alamanni Wyatt is a literary imitator, though for Wyatt as for many French and English humanists Italian and Latin poems are equally acceptable models. Thus Wyatt's psalms and many of his love poems are modelled on Italian works; two of his satires are imitations of Horace; and among his poems are verses translated from Horace, Persius, and Seneca. ${ }^{2}$ Though Wyatt was not required either by his

${ }^{1}$ For a bibliography of Alamanni, see Giuseppe Toffanin, Il cinquecento (Milan, 1954), 5th ed.; for a brief biographical and critical account, see the same volume, pp. $211,455-468,504-508$.

${ }^{2}$ For Wyatt's sources, see Sergio Baldi, La poesia di Sir Thomas Wyatt (Florence, 1953), pp. 218-237; Ruth Hughey, ed., The Arundel Harington Mantiscript of Tudor Poetry (Columbus, Ohio, I960), II ; and Hyder E. Rollins, ed., Tottel's Miscellany 
profession or by the tastes of the English court to try his hand at as many forms as Alamanni experimented with, he clearly followed the humanistic principle of imitation of which Alamanni is a chief representative. It is not surprising, therefore, that Wyatt translated Alamanni's tenth satire, "O vi dirò poi che d'udir vi cale."

Wyatt's "Myne owne John Poynz" is an almost literal translation of Alamanni's tenth satire. Wyatt changes details to suit his own situation, substituting John Poynz and Kent for Thommaso Sertini and Provence. He makes certain references more English, replacing an example drawn from Italian literature with one from Chaucer (11. 50-5 I ), and omitting an allusion to Dante (Alamanni, 1. I 8-cf. Paradiso xvii, 1l. 58-60). And he makes one distinct error, translating "Ma con qual pie potrei color seguire/Che'l mondo pregia" (Alamanni, 11. I6-I 7) as "That cannot dy the coloure blak a lyer" (evidently misunderstanding "color," here short for "coloro," which means "them"). But, with a few exceptions, Wyatt follows Alamanni tercet for tercet, adopting his verse scheme, his logical structure, his rhetoric, and usually his phrases and images. Critics, therefore, have not paid close attention to the changes Wyatt makes. ${ }^{4}$ But through minor modifications Wyatt creates a new poem; and to study his translation together with its original is to perceive a great deal about Renaissance literary practice.

It is really Renaissance literary practice which Berdan attacks when he denies the value of "Myne owne John Poynz." For although Berdan feels that the language of Wyatt's satire is clumsy, ${ }^{6}$ he objects

(1557-1587) (Cambridge, Mass., 1929), II. A. K. Foxwell, A Study of Sir Thomas Wyatt's Poems (London, i $9 \mathrm{II}$ ), pp. 147-152, is not reliable.

Baldi denies that the influence of Horace on Wyatt's satires is certain, but $I$ follow the general opinion.

${ }^{3}$ No. 196 in Collected Poems of Sir Thomas Wyatt, ed. Kenneth Muir (Cambridge, Mass., 1949), the edition I use for Wyatt throughout this paper.

4 Rollins notes merely that Wyatt changes circumstances to adapt the poem to his condition; Miss Hughey says that Wyatt is even more Horatian and urbane than Alamanni-a position directly contrary to that argued in this paper-but she makes no mention of the means Wyatt employs to achieve his effect.

${ }^{5}$ John M. Berdan, Early Tudor Poetry: $14^{8} 5^{-1547}$ (New York, 1931), pp. 476-480. Berdan's assertion that Barclay's satires are preferable to Wyatt's insofar as they are more particular is, though irrelevant to my thesis, worth noting as a sign of his distaste for Renaissance Ciceronianism in particular, and Renaissance artifice in general.

${ }^{6}$ As it occasionally is; but its stately power is properly appreciated by J. J. Jusserand, Histoire littéraire du peuple anglais (Paris, 1904), II, 127. 
to the poem mainly because he thinks it insincere. It is doubtful that Wyatt's biography and his poetical denunciation of the court are, as Berdan suggests, inconsistent: for Wyatt was, as Berdan says (p. 486), a grave and moral man, and though he remained a courtier he may well have sometimes hated the court where his wife was whored and his life perfidiously threatened. But the real question is whether, as Berdan says (p. 467), translation is obviously not self-expression; and whether, as he implies, it is obviously not poetry. This is the question that makes a close comparison of "Myne owne John Poynz" to Alamanni's tenth satire important. ${ }^{7}$

The ostensible purpose of "O vi dirò" is to explain why Alamanni lives in seclusion in Provence; its theme, really, is the pleasures of the mean estate. Alamanni's satire may be divided into five parts: a declaration to his friend Thommaso that the poet will explain why he prefers to live humbly in Provence (11. I-6); a statement that, though the poet does not despise honor (11. 7 - 5), he is incapable of the various evil actions required of a courtier (11. I6-75); an idealized description of his life in retirement (11. 76-84); a satiric picture of various countries in which, in contrast to Provence, the poet is glad not to be (11. 85-96); and a conclusion declaring the poet's content with his present situation (11. 97-109). The poem's structure clearly reveals Alamanni's intention: he means to contrast his way of life, described in parts three and five, to the ways of life satirized in parts two and four.

Wyatt adopts the contrast, and yet he changes both the vision and the structure of his original. Alamanni says that at court one must flatter, rob, and forswear, trample on the innocent and fawn on the powerful; that the Germans wallow bestially in gluttony, and the Romans despise a Christian and a man who will not poison others. But he studies moral corruption only to say that it would vex him to be vicious. He does not expect honesty anywhere, nor does he lay claim to virtue himself. $\mathrm{He}$ is cynical and sophisticated enough to adapt the Horatian theme of the contentment of private life, to a

\footnotetext{
${ }^{7}$ Since Hallett Smith's "The Art of Sir Thomas Wyatt," $H L Q$, IX (1946), 323-355, there have been several essays which recognize that Wyatt's translations of Petrarch express Wyatt's own point of view-for example, J. W. Lever, The Elizabethan Love Sonnet (London, 1956), pp. 22-35 ; Patricia Thomson, "The First English Petrarchans," $H L Q$, XXII (1958-1959), 85-105; and Rudolf Gottfried, "Sir Thomas Wyatt and Pietro Bembo," $N \& Q$, CXCIX (I954), 278-28o. But none of these is concerned with the general problem of literary imitation.
} 
terrible picture of contemporary wickedness. Wyatt does not accept Alamanni's epicureanism-in "A spending hand," 11. I 8-27, he says that to live for oneself alone is to live like a pig. In his hands Alamanni's satire becomes moral-an indignant attack upon the world's corruption, and a dramatic presentation of his own proud integrity.

Through slight modifications of language, Wyatt's translation changes the relationship between the poet and the world. In Alamanni, the poet has elected to leave the court for his greater comfort; in Wyatt, he has been unjustly injured, and retires with a consciousness of his virtue. Thus, in 1.9 Wyatt says that powerful men "strike the stroke," where Alamanni says that they hold the reins; in 1.24 Wyatt says that he suffers for his honesty, where Alamanni says only that he can not be dishonest; in 1.29 Wyatt says that he can not conceal the mistreatment he has received, where Alamanni says that he can not hide from others the dangers that they face. Thus, by minor verbal changes, without Alamanni's warrant Wyatt establishes that he has been ill-treated. Because it is as an ill-rewarded servant that Wyatt pictures himself, Wyatt omits Alamanni's 11. 37-42, which imply that the poet is powerful. In sum, where Alamanni presents himself as a man who relinquishes ambition rather than employ the means that politics require, Wyatt pictures himself as a man whose honest simplicity has occasioned his downfall.

By similar substitutions, Wyatt assumes a pose of triumphant integrity. In his second tercet, Alamanni says that, poor and alone, he moderates his infinite dolor (imitating Petrarch, whose elegant dolor is, however, out of place in a vivid description of corrupt manners). Wyatt, translating this tercet, says that, wrapped within his cloak, he learns to set a law to his will. Wyatt thus transforms Alamanni's poverty to self-sufficiency (the import of the cloak), and his misery to self-control: Wyatt is not suffering from grief but, like a Stoic philosopher, superior to his fortune he is learning the supreme morality of controlling will by reason; he is dedicating himself to that law which the courtiers do not recognize.

Wyatt's purpose, then, is to express his victory through virtue over those who have unjustly mistreated him. To do so, he changes the poem's structure. Where Alamanni's statement of his theme is a promise to tell why he lives in Provence (1. 3), Wyatt's is a promise to explain why he flees courts (1.3); where Alamanni's transition from 
his satire on courts to his picture of his own life contrasts poetry to kingly rule (11. 76-78), Wyatt's contrasts virtue to servile ambition (11. 76-8I); where Alamanni's description of his manner of living details the comforts of private life (11. 79-84), Wyatt's expresses pride, a love of liberty, and a contempt for the mistreatment he has received (11. 83-88). Thus, by a few verbal changes Wyatt transforms a praise of Horatian ease to a declaration of Stoic virtue. The clearest example of Wyatt's structural change is his conclusion. After his denigration of other locales-part of his justification of his residence in Provence-Alamanni says that the people among whom he lives in Provence are, though malicious, merely buffoons; and he concludes that because his neighbors are too stupid to be frightening he lives in that true peace which is more valuable than riches and honor. Since Wyatt's purpose is not to show the advantages of living in Kent but to contrast his simple, honest freedom to the corrupt elegance of those who succeed in the world, his attack on other places functions differently from Alamanni's. It is a progressively more powerful contrast between vice and virtue, leading to a triumphant conclusion in which Wyatt appears morally victorious over those whom Fortune favors:

But here I ame in Kent and Christendome

Emong the muses where I rede and ryme;

Where if thou list, my Poynz, for to come,

Thou shalt be judge how I do spend my tyme. ${ }^{8}$

Wyatt transforms Alamanni's rhetoric as well as his structure. Alamanni's rhetorical technique consists largely of a repetition of certain negatives: his description of the court is composed of repetitions of the phrase "I do not know how," declaring that the poet doesn't know how to flatter, lie, fawn, cheat, etc.; his denigration of foreign countries is composed of repetitions of the phrase "I am not in," saying that the poet is not in France among drunkards, in Rome among poisoners, etc. Alamanni's technique is ideally suited to present an

\footnotetext{
${ }^{8}$ It is possible to read these lines so as to support Miss Hughey's view that Wyatt is yet more urbane than Alamanni- to see them as a graceful invitation to a friend to visit the poet's country home. But the word "Christendome," placed as it is in opposition to the drunkenness of France, the hypocrisy of Spain, and the murderous sacrilegiousness of Rome, can only represent moral good-a vibrant affirmation. And the final two lines show dignity and confidence, an assurance that the poet's way is right, rather than mere hospitality.
} 
emphatic contrast of the poet to the world. But his rhetoric is diluted by his relaxed moral posture. Though he implies that his disinclination to vice is good, Alamanni accepts the world as it is; his refusal to conform to the world is a sign of Horatian wisdom, not of Christian virtue. Wyatt's moral tone is strong: the court's corruption arouses his indignation; his virtue is meant to awaken our admiration; his rejection of the world's ways is a triumph. Therefore, Wyatt adopts Alamanni's rhetorical mode, but redirects it.

First, Wyatt shapes the list in the second part of Alamanni's satire. Where Alamanni, after declaring that he does not know how to live on the bounty of others (11. I7-I 8), enumerates the evil practices he has not mastered without any explicit order, Wyatt begins with a definition of the kind of vice of which he is incapable (1l. I9-2I), gives examples, formally concludes the section (11. 56-57), and then defines the next kind of evil of which he will enumerate examples (11. 58-63). Wyatt's structural clarity makes the variety of his examples more exciting and the cumulative force of his list more emphatic than they are in Alamanni.

Wyatt modifies Alamanni's list to insist that virtue is oppressed while vice is rewarded: he indicates, as Alamanni does not, that the truthful man is abused (1. 73), the crushed innocent scorned (11. 70$7 \mathrm{I}$ ), and the brave man called a coward (11. 45-46); ${ }^{9}$ and he substitutes his own example for Alamanni's in order to expand upon the story of a man who died for virtue (11. 37-42). In keeping with his concern for justice, Wyatt substitutes for Alamanni's cultivated elegance a plainspoken roughness, for Alamanni's light irony a bitter sarcasm. For example, Alamanni says in 11. 55-57:

Dir non saprei Poeta alto, e gentile

Merio, giurando poi che tal non vide

Smirna, Manto, e Fiorenza ornato stile.

('I shouldn't know how to call Merio an exalted, refined Poet, swearing further that Smirna, Mantua and Florence never saw so ornate a style." The flatterer prefers Merio to Homer, Virgil, and Dante.) Alamanni here is satirizing an Osric: it is the outrageousness,

${ }^{9}$ Wyatt's 11. 45-46 may in fact result from a misunderstanding of Alamanni's 11. 53-54. Alamanni says that he wouldn't know how "' pauroso e vile/ Chiamarlo il forte, ch'i Centauri ancise." Alamanni is refusing to praise the bravery of a contemptible coward; it may have been his word order which suggested to Wyatt that he was refusing to sneer at the supposed cowardice of a brave man. 
the poor taste of the flattery that disgusts him. In lines 48-5 I Wyatt treats the passage as though it were concerned strictly with truth and falsity, justice and injustice; in lines $43-44$ he says:

I am not he suche eloquence to boste,

To make the crow singing as the swane;

And he concludes the section (1.57):

My wit is nought-I cannot lerne the waye.

Where Alamanni's distaste stems from a superior refinement, Wyatt's is an expression of his honesty. Wyatt emphasizes his bluntness, as when he says of the hypocrite, in 1. 93, "I meddill not with wittes that be so fyne." By such means Wyatt makes Alamanni's rhetoric express a clear contrast between powerful wickedness and injured virtue.

What Wyatt does to his original may be illustrated by his treatment of Alamanni's 11. 58-63:

Non saprei dentro all' alte soglie infide

Per piu mostrar' amor, contr' à mia voglia

Imitar sempre altrui se piange, o ride.

Non saprei indivinar quel ch' altrui voglia,

Ne conoscer saprei quel che piu piace

Tacendo il ver che le piu volte addoglia.

("If I were across the elevated, treacherous thresholds [of courts] I should not know how against my will to imitate another always, whether he wept or laughed, in order to manifest greater love for him. I should not know how to guess what another wanted, nor should I know how to understand what would be most pleasing, leaving the truth unsaid, since it generally makes men sad.")

This is Wyatt's 11. 52-57:

\section{[I am not he that can]}

Praise him for counceill that is droncke of ale;

Grynne when he laugheth that bereth all the swaye,

Frowne when he frowneth and grone when he is pale;

On othres lust to hang boeth nyght and daye:

None of these poyntes would ever frame in me;

My wit is nought-I cannot lerne the waye. 
Where Alamanni is cultivated, gentle, and disillusioned, Wyatt is blunt and indignant. Wyatt does not translate Alamanni's elegant periphrasis ("alte soglie infide") or his worldly apophthegm ("il ver . . . le piu volte addoglia"). Neither does he convey the implications of "infide" - the sense of the uncertainty of the court's rewards-though they are a major part of Alamanni's meaning. Instead, he expresses his sense of the nature of the men who act as he does not-their mechanical and exaggerated grins and their eager hanging on others become a moral portrait. The first line of this passage is inserted to emphasize the randomness of the flatterer's actions. The final two lines contrast to the flatterer Wyatt's self-portrait. There are, of course, many differences between Alamanni's passage and Wyatt's, among them the difference between the influence of Petrarch and that of Langland and his peers. But the central difference is that where Alamanni considers the unpleasantness of court life, Wyatt contrasts a contemptuous description of the successful courtier with a proud expression of his own honesty.

A comparison between Alamanni's tenth satire and Wyatt's "Myne owne John Poynz" is valuable as an example. It reveals Wyatt's acumen in recognizing and skill in utilizing the techniques of his model. It shows Wyatt expressing his sense that the world is corrupt, that merit is not rewarded, and that he himself has the dignity of virtueand expressing these feelings where they are not really in the work he is translating. I suggest that his other two satires make Horace, and many of his Petrarchan translations make Petrarch, express the same vision, and that thus the translation is an important clue to Wyatt's work. But it is perhaps more important as it reflects on the nature of Renaissance literary imitation. This comparison indicates that a Renaissance poet, even when translating, re-creates his original to bear his own meaning, to express his characteristic ideas. If Renaissance poets do so-as Spenser and Milton certainly do, and as Wyatt, in a lesser form and a lesser poem than theirs, does herethen scholars must recognize that modes of imitation need to be defined. If Renaissance poets imitate in order to achieve their own effects, if they perceive in their models what is not the predominant element there, and if even their translations are a fusion of tradition and the individual talent, then perhaps a study of his imitative work is the nearest approach to an understanding of a poet's vision and art. 